\title{
Pengembangan Instrumen Pengukur Pengetahuan Sumber Daya Air Bagi Siswa SMA/MA
}

\author{
Linda $^{1^{*}}$, Febrianawati Yusup ${ }^{2}$ \\ ${ }^{12}$ UIN Antasari Banjarmasin, Jalan Ahmad Yani Km 4,5 Banjarmasin Indonesia \\ *Alamat Email Koresponden: lindalindalinda1739@ gmail.com \\ diterima: 3 Maret 2020, disetujui: 7 Maret 2020, dipublikasikan: 30 maret 2020
}

\begin{abstract}
This study aims to develop valid research instruments and can be used to measure the knowledge of high school students as equals about water resources. The stages in the development of the instrument carried out were the development of a collection of question items, validation of a collection of question items to school namely to the biology teacher and to the biology lecturer, taking opinion experts, testing the validated instrument, administering the instrument, and calculating the validity and reliability of the instrument. This instrument contains statements to measure knowledge about water resources. The instrument validation phase was handed over to one biology teacher, and two biology education lecturers. The trial of this instrument was conducted on 26 high school students equivalent. The results of this trial indicate that out of the fifteen item items only six items are suitable that can be used to measure the knowledge of high school students regarding water resources. The six question items consist of true and incorrect item items. Cronbach's alpha coefficient is -0.65. According to these findings, it can be concluded that the instrument is invalid and cannot be used to measure students' knowledge of water resources.
\end{abstract}

Keywords: Instrument Development, Knowledge, Water Resources.

\section{PENDAHULUAN}

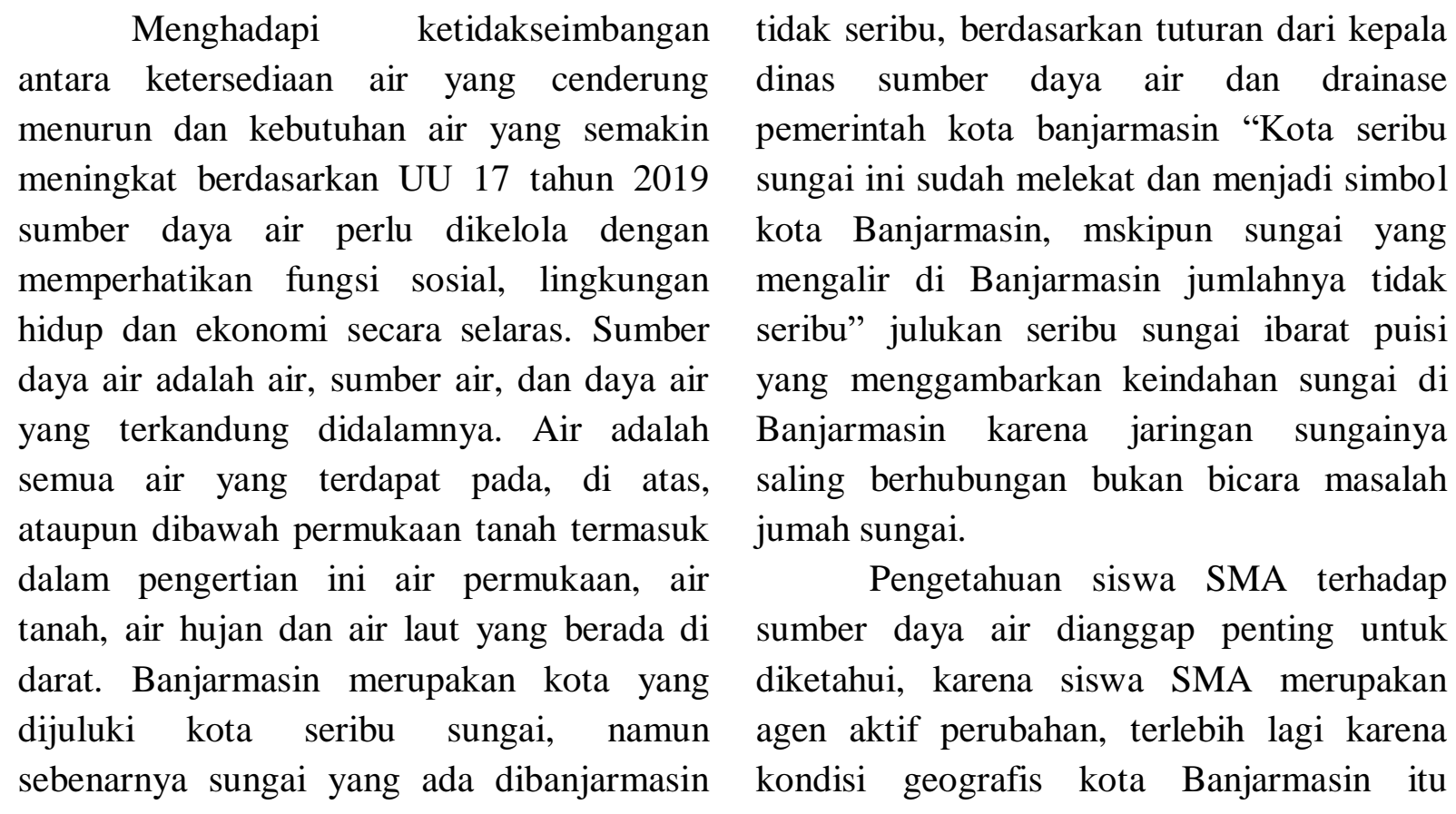


sendiri yang banyak sungainya. Tentu akan sangat bermanfaat jika pendidik seperti guru biologi SMA, memiliki instrumen yang valid dan reabilitas untuk penilaian kognitif mengenai sumber daya air bagi siswa SMA sederajat sesuai dengan keadaan pendidikan yang dilaksanakan di Indonesia.

Pendidik memiliki peran penting dalam mengelola pembelajaran di kelas. Rustaman (2005) menyatakan bahwa dosen dalam menjalankan perannya pada proses pembelajaran, diperlukan penguasaan sejumlah kompetensi yaitu merencanakan, melaksananakan, dan mengevaluasi pembelajaran. Salah satu aspek penting dalam pembelajaran adalah evaluasi/penilaian karena keberhasilan pembelaaran dapat diketahui dengan cara penilaian. Proses evaluasi merupakan salah satu tugas guru yang akan menetukan arah proses pembelajaran selanjutnya. Kegiatan penilaian merupakan kegiatan yang tidak terpisah dari proses pembelajaran dan bagian terintegrasi.

Evaluasi merupakan suatu proses yang sistematis untuk menentukan nilai berdasarkan data yang dikumpulkan melalui pengukuran. Proses pengambilan nilai harus dilakukan secara objektif, dan diusahakan unsur-unsur subjektif tidak masuk sebagai pertimbangan dan penilaian. Dengan kata lain dapat dinyatakan bahwa evaluasi meliputi kedua langkah di depan, yaitu mengukur dan menilai (winarno, 2004). Asmin (2006:45) menjelaskan bahwa peningkatan mutu pendidikan tidak terlepas dari penerapan penilaian yang dapat secara tepat mengukur hasil akhir dari suatu proses pembelajaran artinya untuk menilai hasil akhir dalam pembelajaran diperlukan alat ukur yang berkualitas. Kemampuan guru dalam menyusun instrumen tes tentunya mempengaruhi hasil belajar siswa. Hal ini lah yang mendorong penulis untuk mengembangkan instrumen ini.

\section{METODE PENELITIAN}

Penelitian ini dilakukan pada tanggal 05 Oktober 2019. Pengembangan instrumen ini dilakukan mulai pertengahan bulan Agustus dan uji coba instrumen dilakukan pada awal bulan September.

Penelitian ini melibatkan siswa SMA sederajat di kota Banjarmasin sebanyak 30 orang. Tahap-tahap dari pengembangan instrumen ini mengadaptasi dari Ugulu, et al (2013) melalui enam tahapan berikut. (1)Tahap Pertama: Development Of Item Pool, Sebelum mengembangkan item pernyataan pengetahuan, analisis terhadap potensi materi pada pelajaran biologi SMA sederajat dilakukan terlebih dahulu. Analisis ini untuk menentukan dimensi kognitif yang akan ditanyakan. Studi literatur juga dilakukan untuk mencari referensi dimensi dan item yang bisa digunakan. Total item penyataan yang dikembangkan sebanyak 15 item soal.; (2) Tahap Kedua: Validation Of Item Pool, Draf item pernyataan pengetahuan yang terdiri dari 15 item soal diberikan kepada satu guru ahli SMA sederajat dan dua dosen ahli, untuk dinilai kejelasan kalimatnya, kebahasaannya dan validasi kontennya; (3) Tahap Ketiga: Talking Expert Opinion, Ahli yang dimaksud dalam tahap ini adalah dosen pengampu mata kuliah biologi dan guru pengampu mata pelajaran biologi. Dua orang dosen dan satu orang guru dilibatkan dalam tahap ini untuk dimintai pendapatnya tentang kesesuaian tujuan yang ingin dicapai dengan item soal pernyataan yang dibuat, kejelasan kalimat dalam pernyataan, serta kebahasaan yang dipakai. Item soal yang telah divalidasi, beberapa item soal perlu direvisi sesuai dengan penilaian dan saran dari dosen ahli dan guru. 
Selanjutnya 15 item soal tersebut siap diuji cobakan secara terbatas kepada beberapa sampel yang representatif; (4) Tahap Keempat: Pilot Testing, Uji coba instrumen dilakukan terhadap 26 siswa kelas XI salah satu MAN di kota Banjarmasin. Selama uji coba, siswa diminta untuk menandai item penyataan yang sulit dipahami, item penyataan yang ambigu dan item penyataan yang membingungkan. Hasil uji coba digunakan sebagai referensi revisi berikutnya terhadap instrumen pengetahuan ini; (5) Tahap Kelima: Administration of the Instrumen, Instrumen dengan 6 soal yang telah direvisi dari hasil uji coba selanjutnya di administrasikan terhadap 30 siswa SMA sederajat segera setelah uji coba dan revisi; (6) Tahap Keenam: Calculating Validity and Reliability, Data yang dikumpulkan dari 30 siswa SMA sederajat tersebut kemudian dianalisis menggunakan SPSS (Statistical Package for the Social Sciences) versi 22.

\section{HASIL DAN PEMBAHASAN}

\section{Dimensi Pengetahuan}

Pada dimensi pengetahuan instrumen yang digunakan untuk mengukur pengeteahuan siswa SMA sederajat tentang sumber daya air. Instrumen ini terdiri dari 15 item soal pernyataan yang kemudian diambil 6 item soal pernyataan sesuai dengan hasil uji validitas dan reabilitas.

\section{Hasil Validasi}

Validasi merupakan cara untuk menguji keakuratan suatu instrumen agar dapt digunakan. Instrumen dikatakan valid apabila dapat digunakan untuk mengukur apa yang ingin diukur. Dalam hal ini, instrumen pengetahuan mengenai sumber daya air dikatakan valid apabila benar-benar bisa digunakan untuk penelitian kognitif siswa SMA sederajat mengenai sumber daya air.
Validitas yang dilakukan dalam pengembangan instrumen ini dilakukan dengan meminta pendapat dosen ahli biologi dan guru ahli biologi SMA sederajat tentang kesesuaian tujuan yang ingin dicapai dengan item soal pernyataan yang dibuat, kejelasan kalimat dalam pernyataan, serta kebahasaan yang dipakai. Ada beberapa hasil penilaian dan saran dari dosen dan guru ahli yang harus dipertimbangkan antara lain, kesesuaian item pernyataan dengan dimensinya, penyusunan kalimat yang harus sesuai dengan kaidah penulisan Bahasa Indonesia yang baik dan benar, serta keefektifan dalam penggunaan kata, sehingga beberapa item penyataan perlu direvisi.

Hasil validitas ini selanjutnya digunakan untuk bahan revisi item soal sebelum ke tahap berikutnya yaitu uji coba instrumen.

\section{Hasil Uji Coba}

Uji coba dilakukan sebanyak satu kali. Uji coba intrumen ini melibatkan 26 siswa SMA sederajat kelas XI. Item penyataan pengetahuan yang diuji cobakan berjumlah 15 item penyataan yang terdiri dari 7 item soal benar dan 8 item soal salah.

Dalam uji coba ini, siswa diminta untuk menandai item penyataan yang sulit dipahami, item penyataan yang ambigu dan item penyataan yang membingungkan. Hasil jawaban siswa digunakan untuk menganalisis item pernyataan menggunakan item-total correlation for each item dan koefisien alfa Cronbach dalam software SPSS versi 22. Hasil uji coba digunakan sebagai referensi revisi berikutnya terhadap instrumen pengetahuan ini.

Dari 15 item pernyataan yang diuji cobakan, 6 item soal yang tertinggi dipakai untuk menyusun intrumen, 9 item soal sisanya dieliminasi. Pada 6 item pernyataan 
yang dipakai ini, 2 item pernyataan benar dan 4 item pernyataan salah.

Data yang terkumpul dari 26 siswa setelah uji coba digunakan untuk menganalisis item untuk menyusun instrumen yang berisi item-item penyataan untuk penilaian kognitif siswa SMA sederjat mengenai pencemaran air. Analisis item yang digunakan yaitu item-total correlation for each item dan koefisien alfa Cronbach menggunakan software SPSS versi 22. Dari 15 item soal yang diujikan, seluruh item memiliki realibilitas $-0,65$.

\section{KESIMPULAN}

Dengan nilai Koefisien Alfa Cronbach adalah -0,65, maka instrumen ini dinyatakan tidak valid dan tidak dapat digunakan untuk kognitif siswa SMA sederajat mengenai sumber daya air.

\section{UCAPAN TERIMAKASIH}

Penulis mengucapkan terima kasih kepada, Khairunnisa, M.Pd, selaku ketua jurusan Tadris (Pendidikan) Biologi UIN Antasari Banjarmasin, Febrianawati Yusup, M.Pd, selaku dosen pembimbing yang senantiasa sabar dalam membimbing penulis, Sari Indriyani, S.Pd., M.Pd. dan Istiqamah, M.Pd., dosen Tadris (Pendidikan) Biologi yang tanpa pamrih mau memberikan kritik dan saran untuk kemajuan instrument ini, Tak lupa kepada kedua orang tua yang penulis hormati dan sayangi, terima kasih atas kasih sayang, doa dan bantuannya yang tiada henti diberikan kepada penulis.

\section{DAFTAR PUSTAKA}

Asmin. (2006). Pengaruh Ragam Bentuk Tes Objektif dan Gaya Berpikir terhadap Fungsi Informasi Tes: Penelitian Quasi Eksperimental dengan Analisis Item Response Theory di SMU DKI Jakarta. Jurnal Pendidikan dan Kebudayaan. 062 (12):633-655.
Rustaman, NY. (2005). Stategi belajar Mengajar Biologi. Malang: UM Press.

Ugulu, I., Sahin, M., Baslar, S. (2013). High school students' environmental attitude: scale development and validation. Int J Edu Sci, 5 (4): 415-424.

Winarno, M.E. (2004). Evaluasi dalam Pendidikan Jasmani dan Olahraga. Jakarta: Center Human Capacity Development.

Yusup, Febrianawati. \& Achmad Munandar. (2015). Pengembangan Instrumen Penilaian Sikap terhadap Lingkungan yang Valid dan Reliabel bagi Siswa SMA. Retrieved from https://jurnal.uns.ac.id/prosbi/article/viewFile/67 72/6100. 